\title{
The Stela of Intf from the Middle Kingdom in Cairo Museum
}

(C.G.20561)

\author{
Dr.Fatma Abd Elghany Salem \\ Assistant Professor in Egyptology Dept. \\ Faculty of Archaeology, South Valley University
}

\begin{abstract}
$\underline{\text { Abstract: }}$
The present paper aims to publish and study a stela from Abydos kept at the Middle Kingdom's Store, Cairo Museum (C.G.20561) ${ }^{1}$. It also discusses the meanings of names and titles, copies and translates manuscripts, and comments on the spelling features and marks of the stela. The stela understudy was found by Mareet in Abydos during the excavations of the Egyptian Authority of Egyptology (EAE). It is a funeral rectangular sandstone stela $(62.5 \mathrm{~cm}$ high and $53 \mathrm{~cm}$ wide) documenting the formula of making offerings ${ }^{2}$. It belongs to a person called Intf. The paper concludes that the artistic style, spelling features, and marks of the stela date back to the era of Senusret I Kheperkare (Nectanebo I) of the Twelfth Dynasty.
\end{abstract}

Keywords : Abydos, Stela, C.G. 20561, Intf, Mariette.

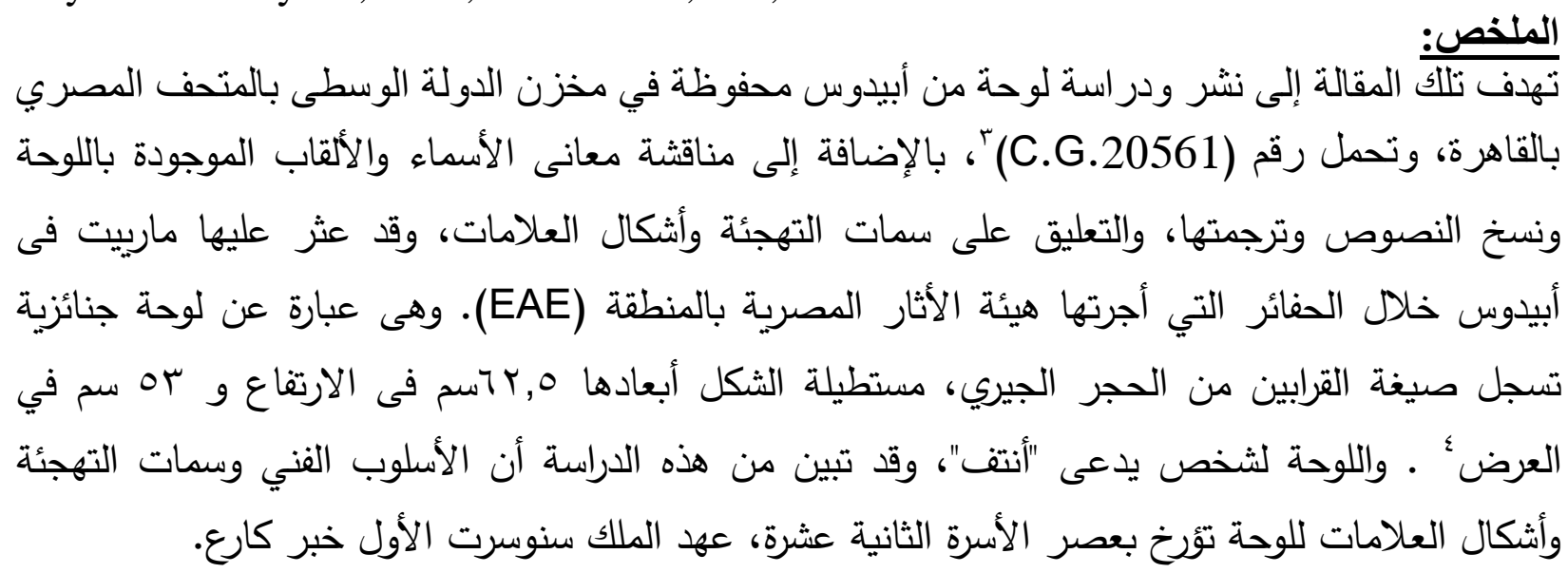

\section{Representations and Text:}

Stela (figure 1, plate 1) is a funeral rectangular sandstone stela of a person called J Intf. The inscriptions are made in low relief and colored blue, and the shapes are engraved in sections deeply. This stela is an excellent artistic work. Moreover, the remains of colors are on the upper edge, whereas the edges are decorated in red and yellow in an up-down strip ${ }^{6}$.

Regarding the coloring of the Middle Kingdom's stelae, a thorough examination of the artifacts kept at the British Museum illustrates that hieroglyphics were primarily accurate and colored black, red, and yellow in the Eleventh Dynasty. Moreover, the artist tended to mimic natural colors. By imitating the natural colors, 
writings and inscriptions seemed natural according to the adopted traditions because hieroglyphic writings were considered actual drawings more than letters ${ }^{7}$. In the era of Senusret I, other colors, such as blue and green, were added, and severity vanished. Furthermore, colors were generally vital but refined and dignified and close to reality ${ }^{8}$.

In the $11^{\text {th }}$ Dynasty, inscriptions were worldly more than religious. No stela has been discovered with a literal religious formula. However, a considerable change took place in the reign of Senusret I when the worldly themes vanished, and stelae were dominated by religious themes, as shown by the discoveries of stelae with pure religious topics 9 .

The upper part of the stela contains three horizontal lines of hieroglyphic text. Moreover, the stela is divided vertically into two sections, with the deceased and his wife standing on the left. The right position is divided horizontally into three rows (levels) in which some relatives of the deceased, mostly brothers, sisters and might be servants, give different offerings. The text reads:

a)3horizontal lines :

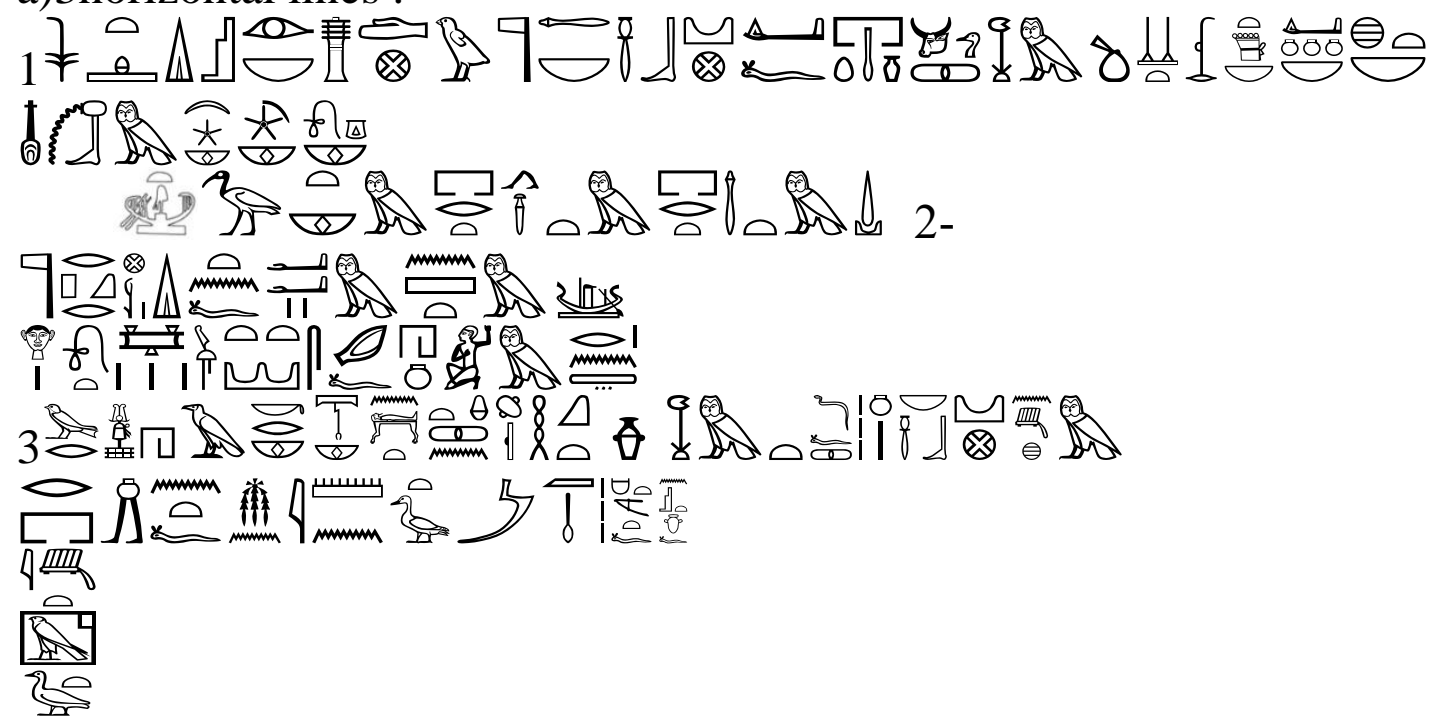

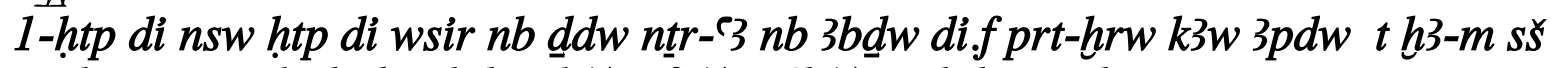
mnht rnpwt nbt hnkt nb ht nb(t) nfr(t) web(t)m 3bdw smdt w3g

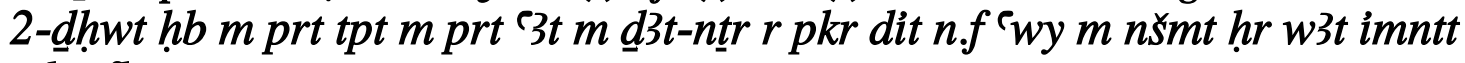
sdim.fhnw $m$ r $n$ 3-t3-wr h3kr hb grh hb $n$ sdrt hasb hnkt h3 $m$ t $d f 3 w n w$ nb $3 b d w$ m im3hw imy-r pr Intf ms n s3t-Imn m3-hrw hmt mrt.fn st-ib. fim3ht s3t hwt-ḥr

1- The king gives offerings and Wsir gives the offering of the Master of Abusir, the great god Master of Abydos gives offerings: Oxen, birds, bread, a thousand incense, clothes, all fresh vegetables, all offerings, and everything beautiful and pure on the festival of the month and half month and the festival of $w 3 g$

2- And in the feast of Thoth, the first great procession, the exit or transit of the god to bagr (the tomb of Wsir in Abydos). Help is offered to in a boat on the western road (the road of the other world) and he hears the invocations at the entrance of

3- Abydos, the festival of haker, the eve of sajret- a thousand of bread and offerings (supplies) of the master of Abydos for the spirit of the healer who 
supervises the house "Intef", the son of Sitamun, his beloved wife who is in his heart the daughter of Hathor ${ }^{10}$.

- The formula "Htp-Di-nsw" was introduced in the $4^{\text {th }}$ Dynasty ${ }^{11}$ and was

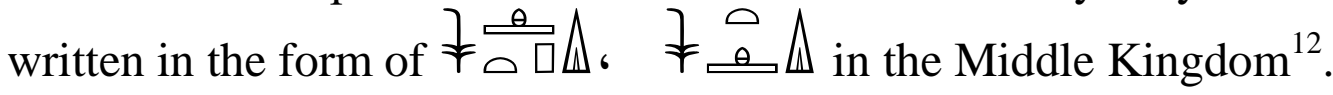

In the common form of "Htp-Di-nsw", "Htp" was inserted between "di" and "nsw" marks ${ }^{13}$.

The letter "t" was commonly written above "Htp" and "sw" marks in the $12^{\text {th }}$ Dynasty ${ }^{14}$.

Since the Middle Kingdom, the rationale behind the formula "Htp-Di-nsw" was that the king gives, gave, or will give an offering to a god in the temple to make the latter do the due role when giving offering in the tomb or anywhere a memorial monument is dedicated to the deceased ${ }^{15}$.

Wsir: Spelling changes took place in writing the noun "Ozer" in the $11^{\text {th }}$ Dynasty. However, the name of god Usir without an assigned symbol was common in the era of Amenemhat III and continued in the following Dynasty. In the early $12^{\text {th }}$ Dynasty, the name Wsir was written with the assigned symbol th. Later, the assigned symbol was often neglected ${ }^{16}$.

It is worth noting that the religion of Wsir was officially introduced in the late $5^{\text {th }}$ dynasty when King "Unas" acknowledged and believed in it along with the sun religion, as shown in the Pyramid Texts. It continued evolving and strong till the Middle Kingdom. Furthermore, adopting the sun religion began to weaken slowly until it vanished in the magic spells. In the Middle Kingdom, the religion of Wsir was the popular and favorable in Egypt. From that time, Abydos and Abusir were the destination of pilgrimage to Wsir, whereas the local funeral god in Abydos known as "Khenti-Amentiu" was worshipped with Wsir, but was eventually mixed with Wsir that became known as "Foremost of the Westerner""

Since the late $11^{\text {th }}$ Dynasty, the deceased who was proved innocent after trial, the phrase "true of voice" was inserted after his name, a victor of the worship of Wsir. Furthermore, the funeral offering yearned for by the spirit of the deceased developed- another piece of evidence of Wsir's victory. Unlike the conventional way of making offerings of the deceased and the god(s) by the king, after the victory of Wsir, the king made the offering to the god, hoping that the god would give a part to the deceased. In other words, the god was theoretically responsible for serving the deceased. Thus, it was in favor of the deceased to be buried next to the temple of the god with accumulated offerings around in addition to the offerings offered by the soul priests and the relatives of the deceased. It is possible that this idea tempted the Egyptians to establish tombs or funeral stelae near the Temple of Abydos ${ }^{18}$.

$N b \underline{d} d w \circlearrowleft$ \&

Pr-WSir (Busiris) was the capital of the ninth nome in Lower Egypt symbolized by ddw the symbol of god Wsir. Thus, it was called "Ddw" after making Usir the deity of the city. It was also called "بر-أوزير-نب جدو", i.e., the home of Usir Master of Ddw ${ }^{19}$. 
Master of Ddw: Writing this title was common until the reign of Senusret III. The title Ddw appeared in the Old Kingdom and continued in the Middle and New Kingdoms. In the $5^{\text {th }}$ Dynasty, it took the form of making offerings. Furthermore, the city was associated with the titles of Wsir, including nb Ddw that appeared in the $11^{\text {th }}$ Dynasty.

This city was mentioned in the Pyramid Texts as a location of worshipping Wsir symbolized with $\underline{d} d{ }^{\text {弯 }}$ in the north and was parallel to Abydos in importance. It was an important city because the parts of the deceased Wsir were collected across Egypt and buried near the city. The festival of Wsir was celebrated by $\operatorname{Ddw}^{20}$ that symbolized the resurrection of Wsir in the Other World, as offering this pillar made the deceased innocent in the Kingdom of the Dead with Wsir ${ }^{21}$.

$n t r-3$ )

The title "ntr-e 7 " " was introduced in the reign of Senusret I. At the time of Senusret III, all titles of Wsir were removed except for ${ }^{22}$ hnty imntyw.

$n b 3 b \underline{d} w \circlearrowleft \bar{l} \sqrt{\frac{U}{3}}$

This title spread in the $12^{\text {th }}$ Dynasty $^{23}$. It appeared in the Old Kingdom and continued in the Middle and New Kingdoms. Wsir was closely related to Abydos more than other cities across Egypt since the Old Kingdom ${ }^{24}$.

Abydos was significant throughout history as the key cult center of Wsir -ancient Egypt's primary funerary god. Many cult structures were dedicated to Wsir, and vast cemetery fields were developed, integrating not only the original population but also nonlocal people who chose to build tombs and commemorative monuments in Abydos ${ }^{25}$.

Regarding the relationship between Ddw and Abydos, there were references to Ddw and North Abydos $3 b \underline{d} w \boldsymbol{w}$ m $h$ and vice versa because Abydos was referred to as Ddw of Upper Egypt, from where Wsir's worship spread across ancient Egypt to replace "Khenti-Amentiu". The arrival of Usir in Abydos was associated temporally with the late Old Kingdom, as shown by the old evidence found in Umm El Qa'āb in the form of fragments of an offering from the Old Kingdom ${ }^{26}$.

- The word $k 3 w-3 p d w$ was written in this formula in the $12^{\text {th }}$ Dynasty ${ }^{27}$.

- The word $m 3^{r} h r w$ (true of voice) was used for the deceased, meaning true of voice or innocent. It was originally used for the god Wsir because each deceased was entitled (Wsir - so and son), meaning (the deceased so and so) or the late ${ }^{28}$.

hmt.f $n$ st-ib.f "His beloved wife in his heart" was an honorary title that often dedicated to the wives of senior statesmen, e.g., ministers, rulers of nomes, and priests. It suggested the respect of the ladies of a family. It was introduced in the $12^{\text {th }}$ Dynasty to the wife of "Khnumhqtep", a ruler of Bani Hasan and a lady called " set Aty". It continued but rarely in the Second Intermediate Period ${ }^{29}$.

娄沓

\section{$3 b d w s m d t$}

Abdw "Monthly Festival": The festival of the beginning of the lunar month was the festival of the new moon "ps $\underline{d n t y w}$ ". It was derived from the verb "ps $\underline{d}$ ", indicating the visible moon in the sky the following day of waning. It was also 
called "tpy $3 b d$ ", i.e., the beginning of the month and "ibd" because it was celebrated on day two of the month. It was an important festival for the deceased in ancient Egypt because offerings were made at the beginning and half of the month. Ancient Egyptians also believed that the soul of the deceased united with the moon. Pyramid Texts highlighted the relationship between the moon phases' festivals and making offerings to the deceased king known as "festival's offerings" because they were celebrated in the beginning of the month. Pyramid Text No. (1001) highly expressed the relationship between the deceased and the moon, as the king said "I will stand among stars because the moon is my brother" ${ }^{\prime 30}$.

smdt "festival of the middle of the lunar month": It was celebrated on day 15 of the lunar month and called i $i$ wr "festival of the full moon" and tpy smdt "the beginning of the middle of the month" ${ }^{, 31}$. Pyramid Texts and coffins indicated the importance of this festival for the Old and Middle Kingdoms because its rites aimed at resurrection in the Other World. Pyramid Text No. (657) reads "Barley is threshed for thee; spelt is reaped for thee; some is offered for the beginning of thy monthly feasts; some is offered for the beginning of thy half-monthly feasts, as something commanded to thee to be done by thy father Geb..." ${ }^{32}$.

बी $w 3 g$ appeared for the first time in the tomb of "Mtn" an official from the Old Kingdom. It was dedicated to the deceased and mentioned in Pyramid Texts no

(716-820-1880-2185) and Coffin Texts $^{33}$. It was an important festival that was closely related to Usir. It was derived from the verb " $w 3 g$ ", i.e., become, shout joyfully, or rejoice. It was celebrated from the $17^{\text {th }}$ night of the first month of flood season $3 h t$ called the "night of $w 3 g$ " till the next day and was dedicated for making offerings to the deceased, especially wine. It was a festival of rejoicing for the live and deceased to share drinking and make food and drinks, especially wine, to the deceased. In the Pyramid Texts, Wsir was described as the "god of wine" $n b$ irp $n$ in the $w 3 g^{34}$.

This festival was dedicated to the death of Wsir and honoring the spirits of the deceased in the journey in the Other World. People made small paper boats and set them toward the west on tombs to indicate the death of Wsir and floated shrines of paper on the waters of the Nile for the same reason ${ }^{35}$. In the New Kingdom $\frac{06}{8,}$, it was celebrated and related to Wsir as it became known as $h b w 3 g$ instead of $w 3 g$ in the Old and Middle Kingdoms. One of its rites was offering sweet and wine to the deceased. In the Middle Kingdom, it was celebrated on the $18^{\text {th }}$ day of the $10^{\text {th }}$ month $^{36}$.

Revelations and invocations revealed much information on some stages, rites, and rituals of festivals. For example,

1. At the beginning of the year's festivals, cressets were light on graves and water was brought to the deceased.

2. In the $w 3 g$, people hoped for a happy journey to their deceased in Abydos by setting samples of boats on the graves towards Abydos ${ }^{37}$.

II 
$\underline{d} h w t h b m$ prt was the $2^{\text {nd }}$ festival in all Mastaba of the Old Kingdom between wp rnpt and tpy rnpt. It was the first day of the New Year. It was first mentioned in the Pyramid Texts as an important festival in which offerings were made for the deceased. It was significant for the deceased because $\underline{d} \boldsymbol{h} w \boldsymbol{t}$ matched Anpu- the god of mummification or associated with Wsir-the god of the dead for rebuilding the body of the dead ${ }^{38}$. It was celebrated on day 22 of the first month of Akhet season $^{39}$.

$w 3 g$ and $\underline{d} h w t$ were important festivals in Thout as recorded and attested in the list of festivals in the tombs of the Old Kingdom. In the Middle Kingdom, w3g was reported celebrated on day $18^{\text {th }}$ of Thout, starting from the night of day $17 . w 3 g$ overlapped with Thout on day 19 of Thout in Habu. In the Middle Kingdom, Thout was celebrated a day before the festival of the god Seker celebrated on day 20 of Thout $^{40}$. Both festivals were closely relatedly because they had a common succession, celebrating male gods and held in Edfu and Dandara within a five-day cycle from the $18^{\text {th }}$ to the $22^{\text {nd }}$ of Thout, celebrating the return of Hathor - Tefnut from Nubia ${ }^{41}$.

The ten agreements concluded between " $h b-d f 3 y$ " the ruler of Assiut with the priests of Wepwawet temple helped define the festivals in which the priests did rites before the deceased:

1- The five days of al-Nasiy 2- New Year's night

3- Morning and day, the first day of the new year 4- The night of festival of Wag 42

$P k r$ : since the Middle Kingdom, it was thought that the tomb of king Djer- a king of the $1^{\text {st }}$ Dynasty was the tomb of god Usir in $P k r$ - Umm el-Qaab current ${ }^{\mathbf{4 3}}$.

$n$ ňmt was Wsir's boat, in which the statue of Wsir was put. The celebration of prt 3 $t$ was the greatest annual feast of Wsir in Abydos since the Middle Kingdom. It began with the procession of the god and Wepwawet opening the way for the procession of Wsir and expelling the enemy. Then, the statue of Wsir appeared in the ship nకmt among the attendants who participated in the scene of expelling the enemies of the god who attacked the boat ${ }^{44}$ because the followers of the god Set appeared attacking the " $n$ šmt" boat of Osiris since the $12^{\text {th }}$ Dynasty, but they were repulsed $^{45}$.

$t 3-w r \stackrel{8}{\circ}$

Wsir was known as $t 3-w r$-the master of the great land, as illustrated in the Pyramid Text No.(222,2 ) till the New Kingdom. $t 3-w r$ was the name of nome no. 8 in ancient Egypt, it's capital Theni ${ }^{46}$. It was mentioned in spell no. 366 (b 798) (b 627) of the Pyramid Texts, meaning Abydos ${ }^{47}$.

\section{$h 3 k r h b \sqcap \&$}

Both festivals $w 3 g$ and $h 3 k r$ were mentioned in a stela from the reign of Senusret I belonging to the supervisor of the sculptors "Shen". $h 3 k r$ was also reported on a stela from the Middle Kingdom and kept at the British Museum for a person called $n h t{ }^{~} n h r$ in the reign of Senusret III. The text of line 10 reads "I may hear chants on the door of Tha Wur on the wonderful night of " $h 3 k r$ ". Moreover, $w 3 g$ and irt $h 3 k r$ were often mentioned in the first parts of the same celebration ${ }^{48}$. 


\section{hb $n$ sgrt}

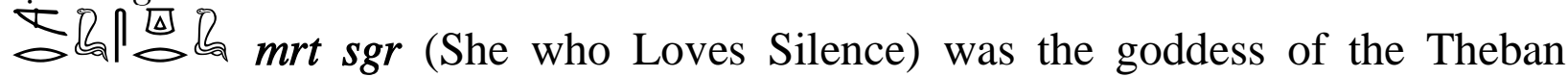
Cemetery, especially the Valley of Kings. The Egyptians imagined her on the top of the valley, supervising the entire cemetery. She loved silence. She was depicted as Cobra worshipped by the workers of the western cemetery in Thebes. She protected the Valley of Kings against thieves by throwing fire in the face to make them blind. ${ }^{49}$ The Egyptians believed that she would be harsh to those who violated the sanctity of the holy tombs, as she would poison them by scorpion or snake bites or, as previously, by blindness ${ }^{\mathbf{5 0}}$.

- The word $m 3^{r}$ hrw (true of voice) was used for the deceased, meaning true of voice or innocent. It was used for the god Wsir because each deceased was entitled (Wsir - so and son), meaning (the deceased so and so) or the late. It was used for Wsir whose rights were acknowledged before the divine court in Iuno ${ }^{51}$.

Hmt.f n st-ib.f "His beloved wife in his heart" was an honorary title that often dedicated to the wives of senior statesmen, e.g., ministers, rulers of nomes, and priests. It suggested the respect of the ladies of a family. It was introduced in the $12^{\text {th }}$ Dynasty given to the wife of Khnumhtep", a ruler of Bani Hasan and a lady called "st Aty". It continued but rarely in the Second Intermediate Period ${ }^{\mathbf{5 2}}$.

Below the hieroglyphic text, the stela is divided vertically into two sections, with the deceased and his wife in a standing position on the left. The right position is divided horizontally into several rows in which some relatives of the deceased, mostly brothers, sisters, and might be servants, make different offerings. On the left side of the owner and his wife:

b) A man (the owner) stands to the right of his wife, holding a long stick in the left hand and a scepter in the right. He wears a short curly red wig, a large necklace with colorful details only left, colorful bracelets, and a kilt to the knee with a straight diagonal line ${ }^{53}$.

The scepter and stick in most stelae of the $11^{\text {th }}$ Dynasty were less common in the reign of Senusret I and following eras. However, they spread in the reign of Amenemhat III $^{54}$.

The scepter starting with the name of the stela's owner was called $s h m$, i.e., authority or rule, similar to a cylinder seal. While tilted, the scepter expressed the offering and direction to the ship. It was a tool for workers in the ship's cabins and resembled a stick $\mathbf{5 5}$.

The wig of the owner: Examining the wigs in Cairo Museum showed that they were mostly human filled with vegetable fibers in the case of large ceremonial wigs. In contrast, the small wigs dated back to later ages were plant fibers with no sign of using wool or horse hair ${ }^{\mathbf{5 6}}$. Beeswax might be used to make the hair of the wig curly and make braids permanently ${ }^{57}$.

The owner wears a large necklace, but only its colored details appear because men used to wear wsh necklaces at the time ${ }^{58}$.

The owner wears colorful bracelets and anklets, which were common among men in the $11^{\text {th }}$ Dynasty but rare in the reign of Senusret I and disappeared in the stelae dated back to Senusret III and Amenemhat III ${ }^{\mathbf{5 9}}$. 
The owner wears a knee-length kilt fastened from the top with a strap with a straight drop line. This kilt appeared in the Old Kingdom, as shown by a raw of men of the $6^{\text {th }}$ Dynasty wearing short kilts with long straps in the Idot Mastaba in Saqqara ${ }^{60}$.

Behind the owner stands his wife to the right, putting her left hand on his left shoulder and holding a lotus in her right hand. She has a familiar female hairstyle and wears a wide collar on the chest and a long tight dress supported by two straps in green. The dress is decorated with a net-like shape and a strap in the upper and lower parts. Furthermore, the lady has bracelets on her arms and anklets on her feet $^{61}$.

Holding lotus was associated with women only. It was first found in stelae dating back to Senusret I but disappeared or became rare after Amenemhat II ${ }^{\mathbf{6 2}}$.

Although women loved adornment and several clothing styles, they did not take this form on the present stela. They wear the usual knotted dresses with one or two straps to fix it. The dresses often have a table-like cut on the chest, or the straps formed a " $v$ " shape. Their colors are often white and green. Moreover, the women wear necklaces, bracelets, and anklets, but none of them appears wearing sandals ${ }^{\mathbf{6 3}}$. e)- Below is an offering table holding food without loaves. Below the table to the left is a bowl in the form of $\bar{l} h s$, and to the right is a bowl with food on a stand. On the top, there is a stand with jugs. The middle jug has three holes with lotus flowers (middle jug) ${ }^{64}$.

d) Three people stand to the left behind each other as follows:

1 - The $1^{\text {st }}$ man holds a jug on his raised right hand and a lotus with its bud in the left hand. His head is shaved and wears a long kilt. His title is in front of his head 皛

imy- $r s \underline{d} 3 w t n b k 3 w$ "overseer the treasury of the bulls' master" ${ }^{\prime 65}$.

2- A woman holds a mirror in her right hand and a cloth strap in the free left hand. Her clothes resemble those of the lady in (b) but with solid green. Her title is in

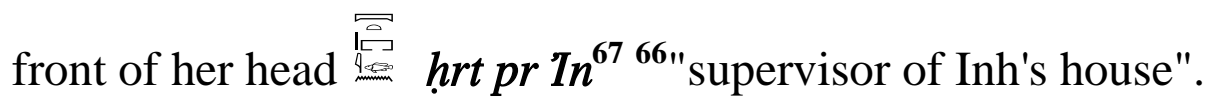

3- A woman carries a box on the right shoulder and hand. In the free right hand, she holds a jug with a handle like a basket. She wears clothes like the woman in

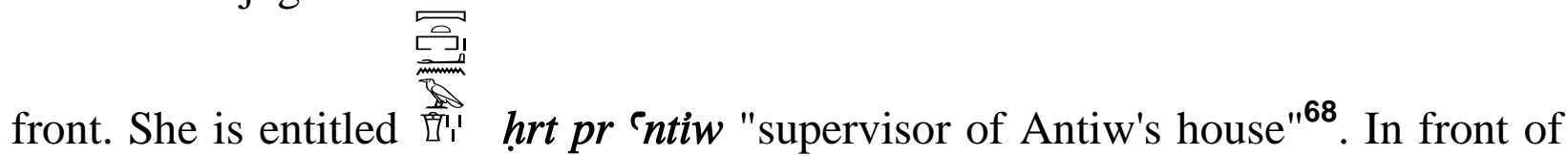
her, there is a vase with a serrated edge from which open and budding lotus flowers emerge ${ }^{69}$.

e) A man stands to the left and raises his right hand as if he speaks. The right hand is free, and the left one holds a book (papyrus roll). The man has a long hairstyle and wears a collar (necklace), bracelets, a long kilt with a piece on the back, and a chest strap with the name is in front of his head In front, there is a stand with three utensils ${ }^{70}$. 
f) A woman stands to the left, holds a basket on her head by her right hand, and holds a lotus in her left hand. She has a common hairstyle and wears a familiar

blue dress with one strap. Her title is in front of her head "supervisor of Sitamun's house"71.

hrt pr s3t Imn The title "hrt pr ", the head of the house, was taken by some women of the $12^{\text {th }}$ Dynasty, namely "Ini", "'ntiw" and "Sitamun"72. This title was not found on the early stelae in the reign of Amenemhat III but spread in later times ${ }^{\mathbf{7 3}}$.

Regarding the man who holds a roll of papyrus, from this period onwards the priest entitled $h r y-h b t$ played a critical funerary role. On the chest, there is a titled band, which undoubtedly suggests his function, who always appears holding a book "papyrus roll" used to recite spells. This depiction was common on stelae dating back to the reign of King Senusret I. It is noteworthy that this priest was often the eldest son of the owner of the stela, as shown in the text ${ }^{74}$. This priest holding a papyrus was depicted for the first time in the tomb of $k 3 \mathrm{~m} \mathrm{hh}$, dated between the beginning of the reign of King Djedkare and the $6^{\text {th }}$ Dynasty. The priest is often accompanied by the statement s3ht in hri hbbt, i.e., the revelation of the chanting priest or hymns of revelation by the chanting priest ${ }^{75}$. 


\section{Results}

\section{Aim and Dating of the Stela}

Aim of the Stela

The religion of Wsir officially appeared in the late $15^{\text {th }}$ Dynasty when the King "Unas" acknowledged and believed in it along with the sun religion, as shown in the Pyramid Texts. It continued evolving and strong till the Middle Kingdom. In the Middle Kingdom, the religion of Wsir was the popular and favorable in Egypt. From that time, Abydos and Abusir were the destination of pilgrimage to Wsir who was known as "Foremost of the Westerner".

Since the late $11^{\text {th }}$ Dynasty, the funeral offering developed. Unlike the conventional way of making offerings of the deceased and the god(s) by the king, after the victory of Wsir, the king made the offering to the god hoping that the god would give a part to the deceased. Thus, it was in favor of the deceased to be buried next to the temple of the god with accumulated offerings around in addition to the offerings offered by the soul priests and the relatives of the deceased. It is possible that this idea tempted the Egyptians to establish tombs or funeral stelae near the Temple of Abydos.

\section{Dating of the Stela}

The stela is dated to the reign of Kheperkare (Senusret I) of the $12^{\text {th }}$ Dynasty in the Middle Kingdom because

1. Coloring inscriptions in the $11^{\text {th }}$ Dynasty was accurate and colored red and yellow. At the time of Senusret I, other colors were added, including blue and green, as shown in the present stela. The colors were generally vivid and real-like.

2. In the $11^{\text {th }}$ Dynasty, inscriptions were worldly more than religious. However, a considerable change took place in the reign of Senusret I when the worldly themes vanished, and stelae were dominated by religious themes, as shown by the discoveries of stelae with pure religious topics.

3. In the early $12^{\text {th }}$ Dynasty, Wsir was written with the symbol th that was not used in later periods.

4. Since the late $11^{\text {th }}$ Dynasty, the name of every deceased who proved innocent after trial was followed by "true of voice".

5. Writing the title " Master of Ddw" was common until the reign of Senusret III.

6. The title "ntr- 397 " was added to Wsir in the reign of Senusret I. At the time of Senusret III, all titles of Wsir were removed except for hnty imnty.

7. $h m t . f n s t-i b . f$ "His beloved wife in his heart" was introduced in the $12^{\text {th }}$ Dynasty given to the wife of "Khnumhtep".

8. Both festivals $h b w 3 g$ and $h 3 k r h b$ were mentioned in a stela from the reign of Senusret I belonging to the supervisor of the sculptors "Shen".

9. It was common to depict the priest hry-ḩbt holding a book "papyrus roll" and reciting spells on stelae from the reign of Senusret I.

10.The features of spelling and marking shapes of the stela date back to the $12^{\text {th }}$ dynasty Senusret I Kheperkare. 


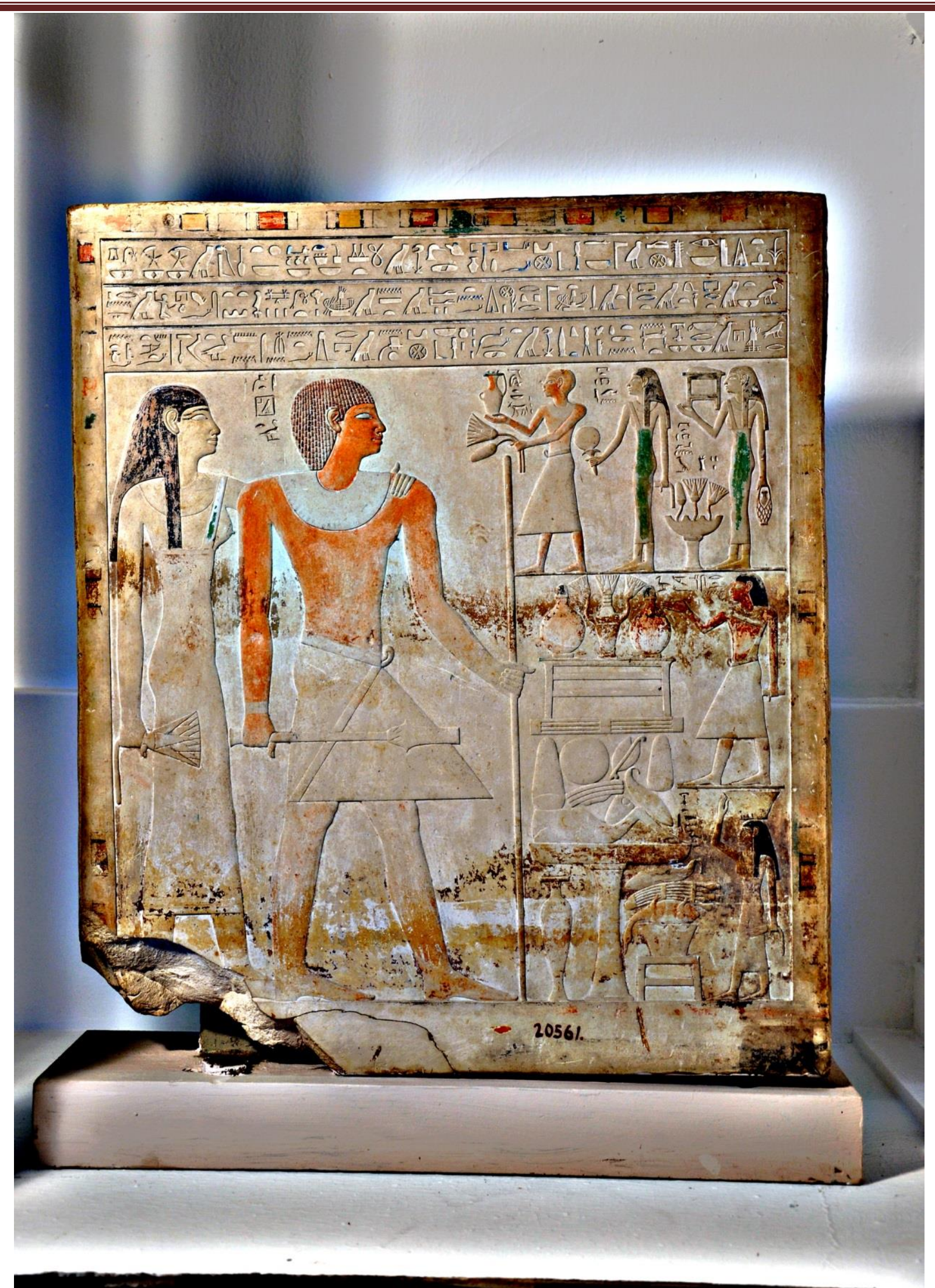

(plate 1) 


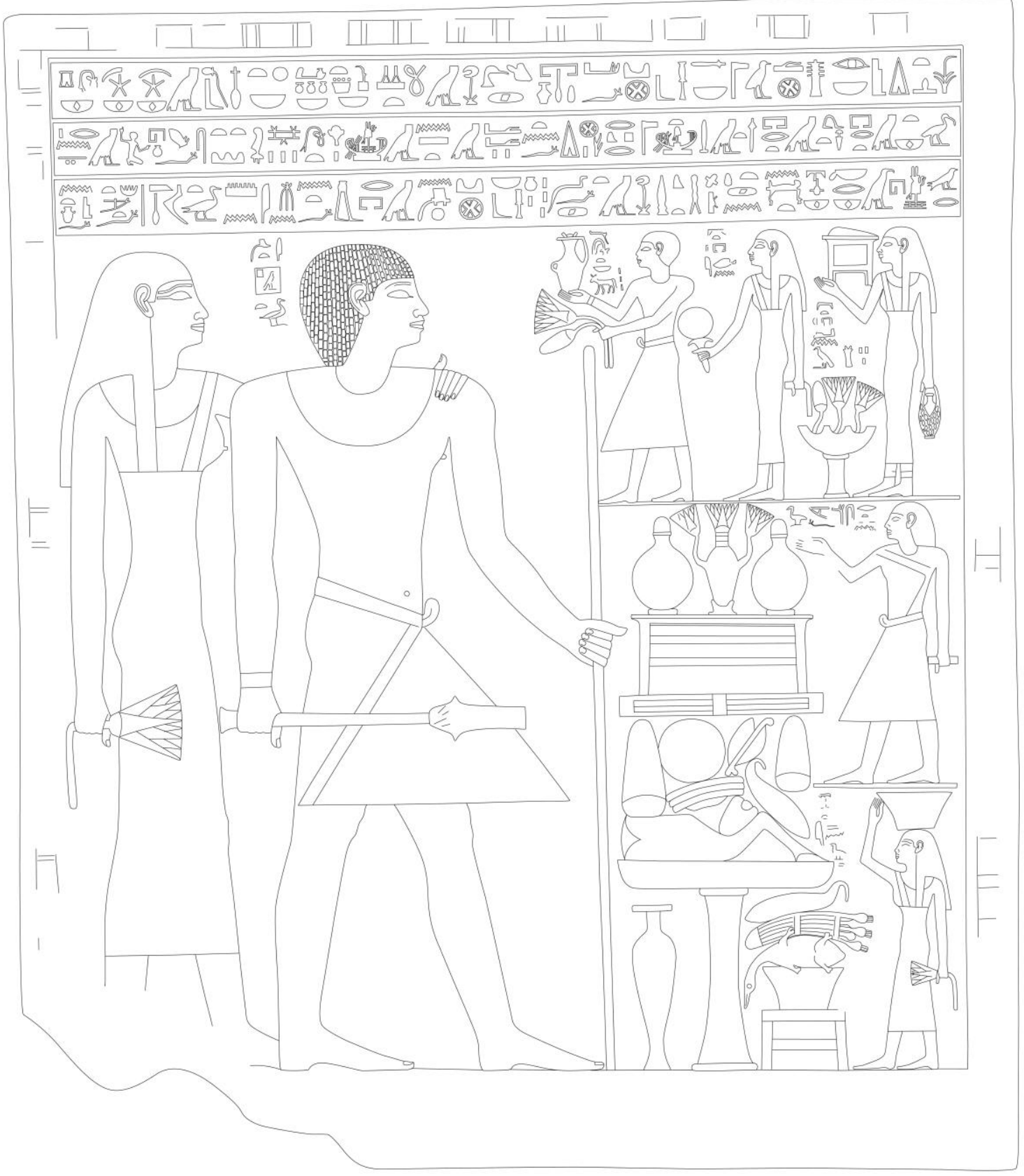

(figure 1) 


\section{Bibliograghy :}

1. Altenmuller, H., : "Feste", LA 11, Wiesbaden, 1977.

2. Bennet, C.J.C.,: " Growth of the Htp-di-nswFormula in the Middle

3. Frank, D., The Middle Kingdom offering Formulas, (JEA89),2003.

4. Gardiner: Egyptian Grammar, third Ed. Oxford, 1982

5. Gillian, V.,E.,: pharaonice Egyptian clothing, in "Studies in Textile And Costume History" Leiden, 1993,Vol.2.

6. Gwyn, J., "Osiris", in Oxford Encyclopedia of Ancient Egypt 11, Oxford. 2001.

7. Ilin-Tomich,A.,'Changes in the Htp-di-nsw Formula in the late Middle ;ingom and the second intermediate period", ZAS 138,2011.

8. Johua J. Mark, "Festivals in Ancient Egypt " Ancient History Encyclopedia, 2017 . https://www.worldhistory.org/article/1032/festivals-in-ancientegypt/\#books_preview

9. Kingdom" JEA,Vol.27,1941.

10.Lucas,O.B.E., F.I.C : Ancient Egyptian Wigs, 1930.

11.Mariette, Abydos, 11 .

12.Muller, H. W., Die Totendensteine des Mittleren Reiches, ihre Genesis, ihre Darstellungen und ihre composition, MDAL;4,1933.

13.Peter Kaplony: :"Zepter" LA,V1, Wiesbaden,1986.

14.Pfluger,K.,:" The private funerary stelae of the Middle Kingdom and their of the importance for the study of Ancient Egyptian History ( JAOS ) Vol.67, London 1947.

15.Porter \& Moss: Topographical Bibliography OF Ancient Egyptian Hieroglyphic Texts, Reliefs, And Panintings,OXFORD,1960.

16.Ranke,H.,: Die Agyptishen Personnen Nomen, Gluckstadtm 1935, Band 1.

17.Redford, The Oxford Encyclopedia, Vol.1, Oxford 2001.

18.Schafer \& Lang. C.G. Des Antiquates Egyptiennes du Musee Du Cairo, Grab-und Denksteine Des Mittleren Reichs.

19.Selim,S., The stela of Hr-wDAw in Cairo Museum (JEA1332), SAK28,2000.

20.Smither,p.,c " The writing of Htp-di-nsw in the Middle and New Kingdom ", JEA, Vol.25,1939.

21.Worterbuch Der Aegyptischen Sprache, Berlin 1971.

1- أحمد محمود عيسي: الحج والزيارات الجنائزية والرمزية في المناظر والنصوص المصرية

القديمة، رسالة ماجستير غير منشورة، كلية الآثار، جامعة القاهرة ؟99 1.

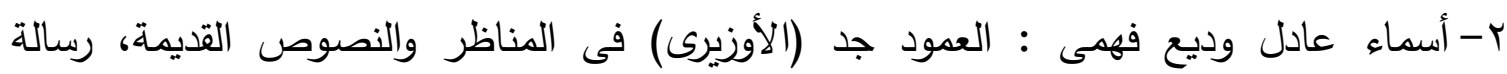

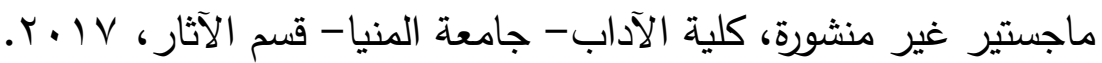

r- ثناء جمعة الرشيدى : ألقاب آلهة مجمع أونو (هليوبوليس ) منذ الدولة القديمة وحتى نهاية

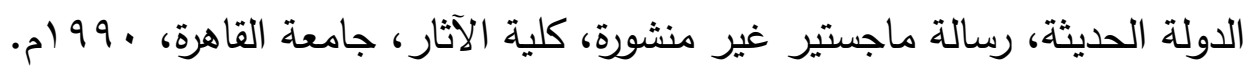


ع - - دعاء محمد محمد بدر الدين : صور وتعبيرات الثواب والعقاب فى المصادر الأدبية والدينية

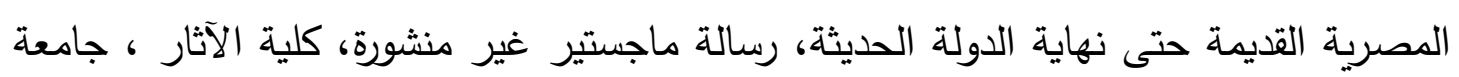

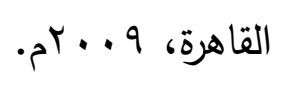

ه-رحاب عبد المنعم عبد الصمد باظة : القمر فى مصر القديمة حتى نهاية عصور الدولة

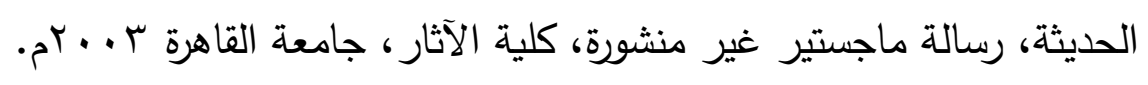

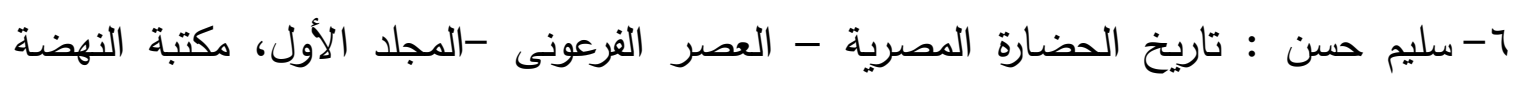
المصرية.

V - عائثة عبد العال : لوحات أفراد الدولة الوسطى (مجموعة الدتحف الدصرى بالقاهر)، رسالة

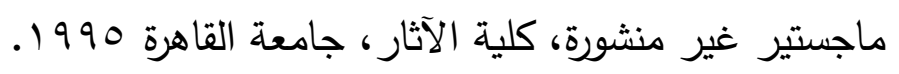

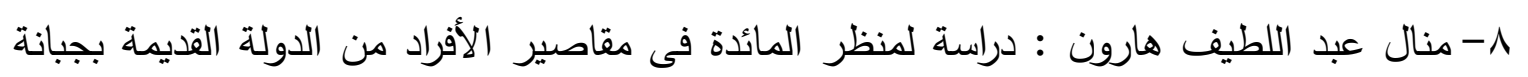

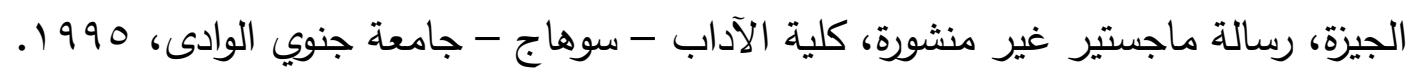

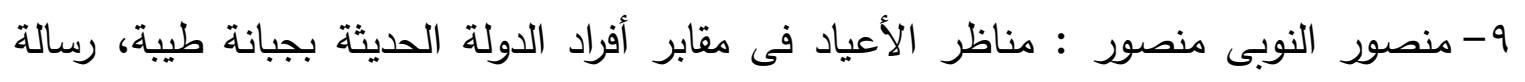

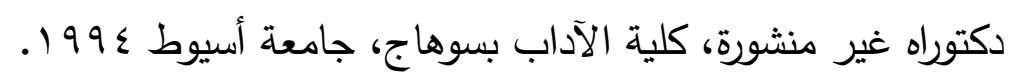

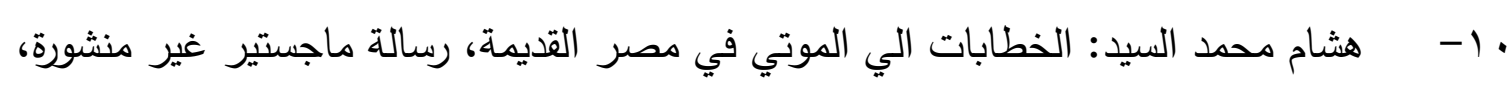

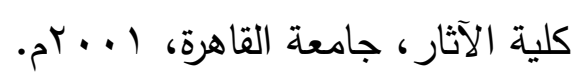

11- هيام حافظ رواش: التجمعات الثبعبية في مصر القديمة، رسالة دكتوراه غير منشورة، كلية

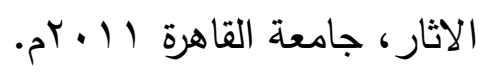


${ }^{1}$ Schafer \& Lang. C.G. Des Antiquates Egyptiennes du Musee Du Cairo, Grab-und Denksteine Des Mittleren Reichs, p.12.

${ }^{2}$ Mariette, Abydos, $11, \mathrm{pl} .53$, a

3 -Schafer \& Lang. C.G. Des Antiquates Egyptiennes du Musee Du Cairo, Grab-und Denksteine Des Mittleren Reichs, p.12.

${ }^{4}$-Mariette, Abydos, 11, pl.53,a

5 行 Kingdom (P\&M.,1, P.437,386). There is now little to mark the site of the tombs, but many stela that must have come from the cemetery of Intf are in museums. The numbering is that of Winlock, the Theban Necropolis in Middle Kingdom in Amer. Journ. Sem. Lang. Lit. xxxii, Oct. 1915, pp.1-37, where the full history of the finds is given; see also Steindorff, Dit Konige Mentuhotep und Antef in A.Z. xxxiii,7796.(P\&M.,1,P.33).

Reichs,I,177-8.(P\&M.,1.P.35,

${ }^{6}$ Schafer \& Lang, op.cit, p.194.

${ }^{7}$ Pfluger, K., "The private funerary stelae of the Middle Kingdom and their importance for the study of Ancient Egyptian History (JAOS) Vol.67, London 1947, p.135.

${ }^{8}$ Pfluger, K., Ibd.

${ }^{9}$ Pfluger, K., op.cit., p.128.

${ }^{10}$ The name was frequently mentioned in this form 3 in the Middle Kingdom Kairo $20531 \mathrm{f}$. $20581 \mathrm{~b}$ 4; Mogensen and in an older form in a stela in the Cairo Museum (Ranke, H.,: Opcit., B 1, p.291,14.)

${ }^{11}$ Muller, H. W., Die Totendensteine des Mittleren Reiches, ihre Genesis, ihre Darstellungen und ihre composition, MDAL;4,1933,P.185.

${ }^{12}$ Smither,p.,c " The writing of htp-di-nsw in the Middle and New Kingdom ", JEA, Vol.25, 1939,p.34

${ }^{13}$ Frank, D., The Middle Kingdom offering Formulas, (JEA89),2003.P.39.

${ }^{14}$ Smither,p.,c; op.cit, p. 34.

${ }^{15}$ Gardiner: Egyptian Grammar, third Ed. Oxford, 1982, p.172.

${ }^{16}$ Bennet, C.J.C.,: " Growth of the htp-di-nswFormula in the Middle Kingdom" JEA, Vol.27, 1941, p.78.

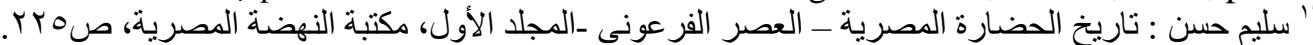

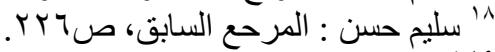

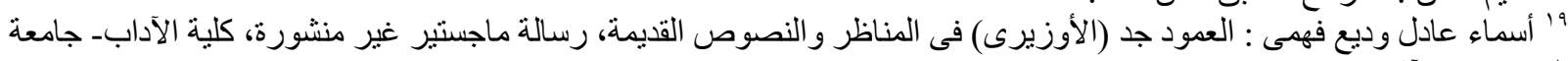

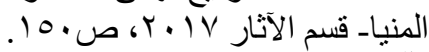

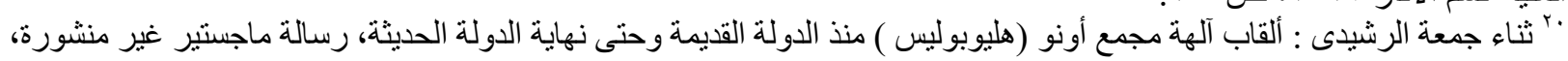

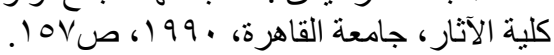

${ }^{22}$ Bennett, op-cit,p.80

${ }^{23}$ Selim,S., The stela of $h r-w d \underline{w} w$ in Cairo Museum (JEA1332), SAK28,2000,P.254.

${ }^{25}$ Redford, The Oxford Encyclopedia, Vol.1, Oxford 2001, p.7

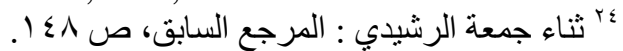

ابكمد محمود عبسي: الحج و الزيارات الجنائزية والرمزية في المناظر و النصوص المصرية القديمة، رسالة ماجستير غير منشورة، كلية

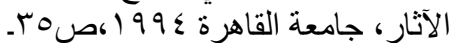

${ }^{27}$ Ilin-Tomich,A.,"Changes in the Htp-di-nsw Formula in the late Middle ;ingom and the second intermediate period", ZAS 138,2011, P.24.

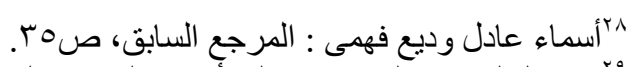

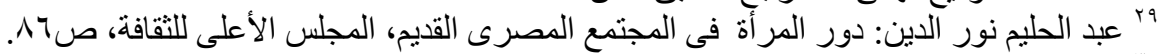

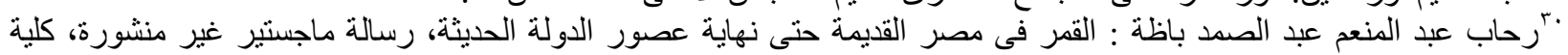

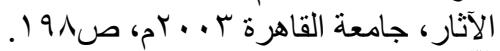

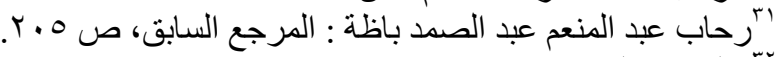

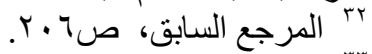

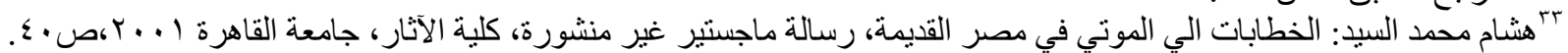

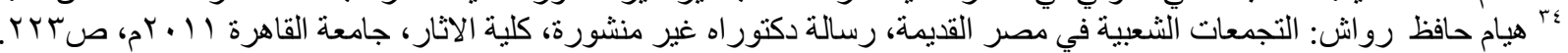

${ }^{35}$ Johua J. Mark, "Festivals in Ancient Egypt "Ancient History Encyclopedia, 2017.

https://www.worldhistory.org/article/1032/festivals-in-ancient-egypt/\#books_preview "rرحاب عبد المنعم عبد الصمد باظة : المرجع السابق ، صع بr. 
"rrvصور النوبى منصور : مناظر الأعياد فى مقابر أفر اد الدولة الحديثة بجبانة طيبة، رسالة دكتور اة غير منشورة، كلية الآداب بسوهاج،

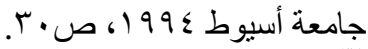

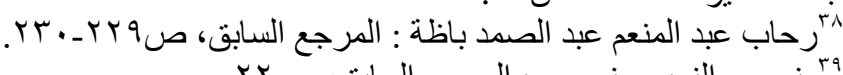

${ }^{40}$ Altenmuller, H., : "Feste", LA 11, Wiesbaden, 1977, p.174.

${ }^{41}$ Altenmuller, H.,: op-cit, p.175.

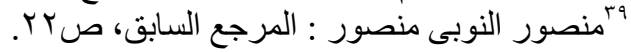

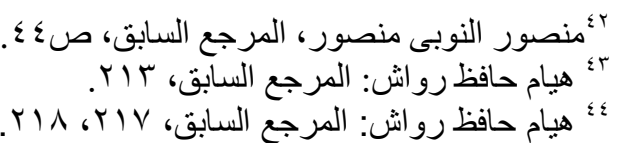

${ }^{45}$ Gwyn, J., “Osiris”, in Oxford Encyclopedia of Ancient Egypt 11, Oxford. 2001, 618.

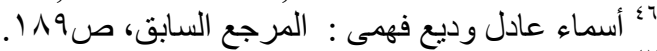

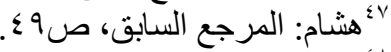

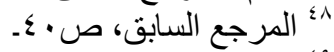

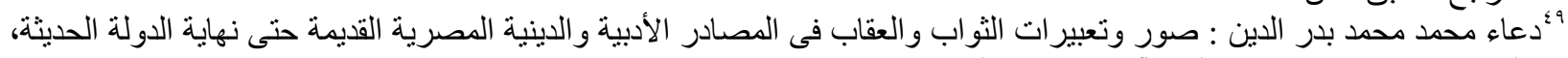

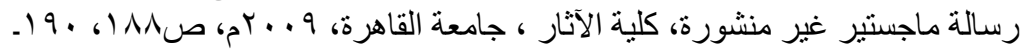

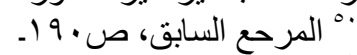

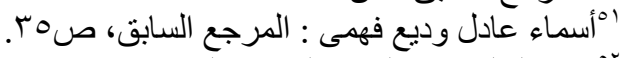

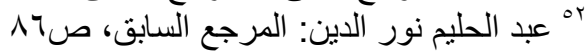

${ }^{53}$ Schafer \& Lang. C.G.op.cit. p. 195.

${ }^{54}$ Pfluger, op.cit, p, 130.

55 Peter Kaplony: :"Zepter" LA,V1, Wiesbaden, 1986,1374.

${ }^{56}$ Lucas,O.B.E., F.I.C : Ancient Egyptian Wigs, 1930, p.196.

${ }^{57}$ Lucas,O.B.E., F.I.C.op.cit. :, p.34.

${ }^{58}$ Schafer \& Lang. C.G.op.cit. p. 195.

59 Pfluger, op.cit, p, 130.

${ }^{60}$ Gillian, V.,E.,: pharaonice Egyptian clothing, in "Studies in Textile And Costume History" Leiden, 1993,Vol.2, p.58.

61 Shefer\&Lang: op-cit, p.195.

62 Pfluger, op.cit, p, 130.

זٓعائشة عبد العال : لوحات أفراد الدولة الوسطى (مجموعة المتحف المصرى بالقاهرة)، رسالة ماجستير غير منشورة، كلبة الآثار،

64 Schafer \& Lang, op-cit, p.195.

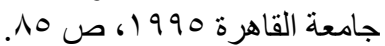

65 Ibd.

${ }^{66}$ Schafer\& Lang, op.cit., p.195.

$67<\frac{6}{1}, 4$

This name was common in the Middle Kingdom : Berlin 7312 D. ; Schfer, Prestergraber S.34 bis 37 ( Var. von in-htp); Kairo 20031 c. $20233 i$.

Also, in the Middle Kingdom : Berlin 1188 B.; Brussel, Speleers 75; Kairo 20268 a. c. usw (Ranke,H.,:

Die Agyptishen Personnen Nomen, Gluckstadtm 1935, Band 1 p.32, 21

${ }^{6}$ WB, 1,P.206

${ }^{69}$ Schafer\& Lang, op.cit., p. 195.

70 Ibd.

Tा $\rightarrow$ Ranke, H.,: Op-cit., B 1, p.86,23.

${ }^{71}$ Schafer \& Lang, op-cit, p.196.

व Museum

D 18 Recueil 22,107 (Ranke, H.,: Op-cit., B 1, p.280,23).

${ }^{73}$ Pfluger, op.cit, p, 129.

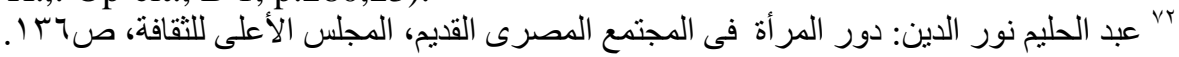

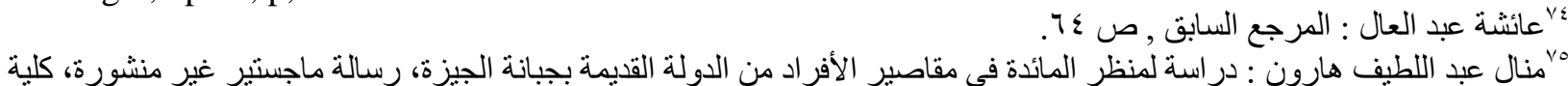

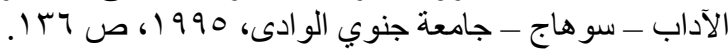

